\title{
The Compressive Strength of Unfired Clay Brick with Sugarcane Bagasse Fiber (SBF) and Bio-Enzyme Reinforcements
}

\author{
Novita Hillary Christy Damanik ${ }^{1}$, Dalhar Susanto ${ }^{1 *}$, Emirhadi Suganda ${ }^{1}$ \\ ${ }^{1}$ Department of Architecture, Faculty of Engineering, Universitas Indonesia, Kampus UI Depok, Depok \\ 16424, Indonesia
}

\begin{abstract}
The architecture and construction industries play an important role in achieving sustainable development goals, particularly environmental ones. These industries currently contribute to high carbon emissions and high energy consumption, as common building materials are among the leading causes of environmental damage. The production of earthen materials, namely clay brick, requires a great deal of energy and emits carbon to the atmosphere in the kilnfiring process. Previous studies have used natural fibers, such as sugarcane bagasse fiber (SBF), and fermented vegetable extracts as reinforcements for use in unfired clay brick. This paper aims to investigate the effects of SBF and bio-enzymes as reinforcements on the compressive strength of unfired clay brick. The experiment produced four types of specimens, each one with the same composition ratios but containing different ingredients. A total of 120 brick samples measuring 50 $\mathrm{mm} \times 50 \mathrm{~mm} \times 50 \mathrm{~mm}$ were produced manually. They were cured for 28 days at a room temperature of $28 \pm 2^{\circ} \mathrm{C}$ before their compressive strength was measured. The results showed that adding SBF to the samples increased their compressive strength. Moreover, adding both SBF and bio-enzymes led to the highest compressive strength measurements compared to the other specimens.
\end{abstract}

Keywords: Bio-enzymes; Soil reinforcement; Soil stabilizer; Sugarcane bagasse fiber (SBF); Unfired clay brick

\section{Introduction}

Clay brick, an earthen building material, has been used for a long time. The sun-dried brick has been first used circa 8000 B.C while the fired brick has been used circa 4500 B.C (Smith et al., 2016; Zhang, 2013). Clay brick is popular in wall construction, especially in developing countries. Thousands of years ago, sun-drying was the most common technique for producing clay brick; sometimes natural fibers, such as straw, were added to the clay mixture as a reinforcement. This method produces no carbon emissions and consumes little energy in the production process (Yetgin et al., 2008). Nowadays, the most common clay brick production method is kiln-firing following sun-drying. In 2013, 1.391 million units of brick were produced globally (Zhang, 2013). This amount is predicted to increase alongside the development of the construction industry and population growth (National Statistics, 2015). Brick is in demand because it is sturdy, relatively cheap (Hall and Djerbib, 2004), fire-resistant (Deboucha and Hashim, 2011), possesses desirable thermal and acoustic properties (Hall and Djerbib, 2004), and is easily obtained (Deboucha and Hashim, 2011).

*Corresponding author's email: dalhar3001@yahoo.com, Tel.: +62-21-7863512; fax: +62-21-7863514 doi: 10.14716/ijtech.v11i7.4526 
The purpose of firing is to strengthen the clay soil to become as hard as stone. Unfortunately, the process of making per one fired brick emits $0.4 \mathrm{~kg}$ of $\mathrm{CO}_{2}$ and consumes around 2 kWh (Munoz Felasco et al., 2014). Previous studies related to unfired clay brick production have included added materials as reinforcements to create what is commonly known as reinforced brick. Some of the studies used natural plant fibers, including straw (Binici et al., 2005), sisal (Njau and Park, 2015), coir (Danso et al., 2015), and sugarcane (Saccharum officinarum) bagasse fiber (SBF) (Danso et al., 2015; Salih et al., 2020). The use of cement as an additive in clay brick is also common because of its mechanical strength, but it is less environmentally friendly given the high energy costs and $\mathrm{CO}_{2}$ emissions that accompany cement manufacturing (Zhang, 2013; Marcelino-Sadaba et al., 2017; Joglekar et al., 2018). The production of one tonne of cement consumes around 5.6 GJ of energy and emits approximately one tonne of $\mathrm{CO}_{2}$ that contributes $7 \%$ of emissions to the atmosphere (Shubbar et al., 2018). A more environmentally friendly reinforcement or stabilizer is thus required to produce unfired clay brick.

The use of sugarcane bagasse in the form of ash as a reinforcement has been examined in several studies because it contains $\mathrm{SiO}_{2}$ which acts as a binding agent when fired. However, even so, the study of sugarcane bagasse in the form of fiber is not often conducted despite the material's high cellulose content, which adds strength to a material. Moreover, $\mathrm{SBF}$ is relatively cheap and abundantly available in Indonesia in the form of waste (Agunsoye and Aigbodion, 2013). The addition of SBF to unfired clay brick improved compressive strength when the SBF was cut to an optimum length of $15 \mathrm{~mm}$ and comprised $5 \%$ of the total clay mixture. Generally, the compressive strength values ranged from $1.82 \mathrm{MPa}-3.98$ MPa (Salih et al., 2020). Another study was also conducted using SBF in which optimum compressive strength was obtained using $80 \mathrm{~mm}$-long fibers that yielded ranges between 1.07 MPa-1.13 MPa (Danso et al., 2015).

Bio-enzymes have also been tested as a soil stabilizer in road construction (Vedula et al., 2007). A bio-enzyme is a non-toxic and natural liquid extracted from vegetables (Rajoria and Kaur, 2014). Bio-enzyme directly affects organic matter in soil, as well as biodegradable minerals and nutrients. Bio-enzyme works effectively in soil containing organic material that has not been sterilized. It attaches to microbes contained within soil and cause them to bond with each other. After that, the microbes reduce the surface tension of the water in the soil, which encourages rapid and thorough penetration of moisture. This leads to a cementation process whereby smaller soil particles combine to fill gaps in the soil, thus forming a dense layer (Chatrada, 2009).

Another study employed liquid bio-enzyme from fermented vegetables to be added to a unfired clay brick mixture (Dzulkifli et al., 2018). Five types of vegetables were used in this experiment: cucumber (Cucumis sativus), spinach (Spinacia oleracea), water spinach (Ipomoea aquatica), cabbage (Brassica oleracea), and cowpea (Vigna unguiculata). These vegetables were chosen for their soil-stabilizing minerals: calcium, iron, and silica. Besides the extraction of fermented vegetable juices, the researchers added eggshell powder as a calcium additive to encourage bio-cementation. The results showed that the compressive strength of the mixture reached $0.062 \mathrm{~N} / \mathrm{mm}^{2}$. By combining bio-enzymes from fermented vegetable extracts with SBF as an organic material in clay mixtures, it is hoped that compressive strength can be improved and meet the standards of conventional brick or fired clay brick.

The present research is focused on the mechanical properties, specifically the compressive strength, of the proposed brick mixture to determine its load carrying capacity and sustainability in wall construction. This research aims to investigate the effects of SBF and bio-enzymes on the compressive strength of unfired clay brick and thus contribute to 
the literature on building material technology. This paper is also relevant to researchers who work in the field of sustainable building material development.

\section{Methods}

\subsection{Raw Material Preparation}

The raw materials for the experiment were prepared. Clay soil, the main ingredient, was obtained from Plered, Purwakarta, Indonesia, which is famous for clay products such as pottery, tile, and brick. The SBF was obtained near Depok, West Java, Indonesia, as it was readily available there in the form of waste. The SBF was sun-dried and cut into lengths of approximately $15 \mathrm{~mm}$, the optimum length as defined by Salih et al. (2020). The bio-enzyme was produced using five types of vegetables: cabbage (Brassica oleracea), cucumber (Cucumis sativus), cowpea (Vigna unguiculata), spinach (Spinacia oleracea), and water spinach (Ipomoea aquatica). Other ingredients in making the bio-enzyme were water and brown sugar. The ratio of brown sugar to vegetables to water was 1:3:10, respectively. A three-month fermentation process was required before the bio-enzyme could be used.

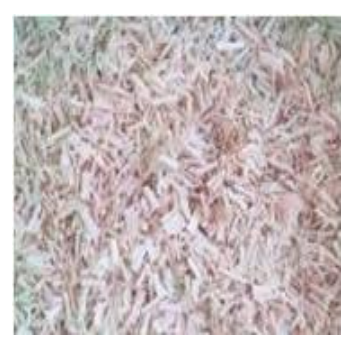

(a)

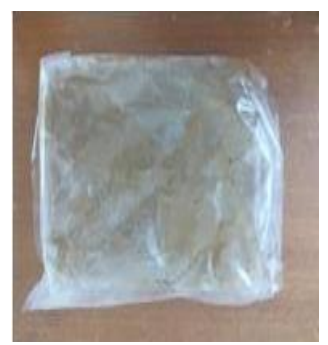

(b)

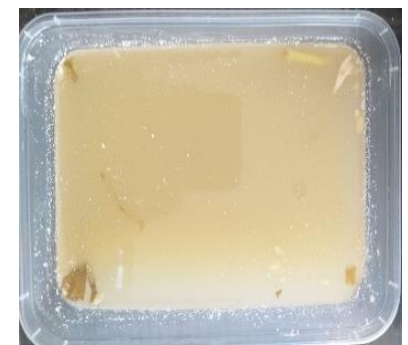

(c)

Figure 1 Raw materials: (a) SBF; (b) Clay; and (c) Bio-enzyme liquid

\subsection{Sample Production}

Four sample mixtures were prepared: a control sample (C), a sample with bio-enzyme $(\mathrm{X})$, a sample with SBF (Y), and a sample with both bio-enzyme and SBF (XY). The dimensions of the samples produced in the wooden mold were $50 \mathrm{~mm} \times 50 \mathrm{~mm} \times 50 \mathrm{~mm}$ for use in a compressive strength test. There were 30 bricks for each sample, each coded from 1-30. The $C$ sample contained only clay with $5-10 \%$ water content, the $X$ sample contained only clay with 5-10\% bio-enzyme as liquid content, the Y sample contained clay with 5\% SBF and 5-10\% water as liquid content, and the XY sample contained clay with 5\% SBF and 5-10\% bio-enzyme as liquid content, as shown in the following table.

Table 1 Samples composition

\begin{tabular}{ccccccc}
\hline Sample & Clay (\%) & Water (\%) & Bio-enzyme (\%) & SBF (\%) & Total & Sample Codes \\
\hline C & 100 & $5-10$ & - & - & 30 & C1-C30 \\
X & 100 & - & $5-10$ & - & 30 & X1-X30 \\
Y & 95 & $5-10$ & - & 5 & 30 & Y1-Y30 \\
XY & 95 & - & $5-10$ & 5 & 30 & XY1-XY30 \\
\hline
\end{tabular}

The samples were produced based on composition ratios. The raw materials were poured into a large bowl and mixed by hand for five minutes until even and homogenous. Before molding, the wooden mold was lubricated with water to prevent sticking. The mixture was compacted to its full depth. The excess mixture was then trimmed with a ruler as a straightedge to level it with the top of the mold. After that, the samples were manually removed from the mold and cured at room temperature for 28 days before compressive 
strength tests were conducted. The 28-day curing process was observed as the optimal period for increasing compressive strength and inducing the bio-cementation process (Dzulkifli et al., 2018).

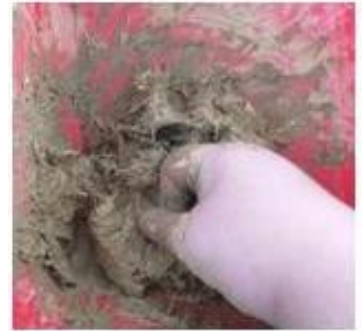

(a)

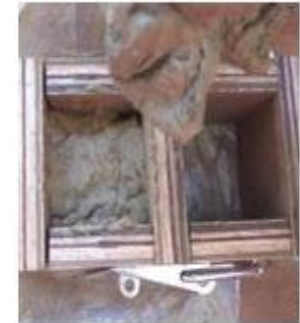

(b)

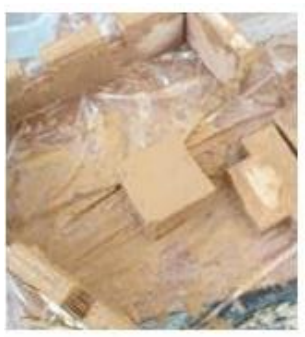

(c)

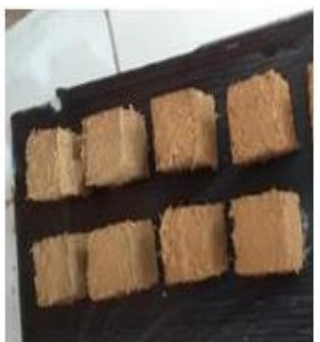

(d)

Figure 2 Steps in production: (a) Mixing; (b) Molding; (c) Releasing from the mold; and (d) Curing

\subsection{Test Procedure}

According to the Indonesian standards, Standar Nasional Indonesia (SNI), the value of compressive strength is obtained from the average of a total of 30 samples. The test was carried out with a $50 \mathrm{kN}$ Shimadzu Autograph AG-IS universal testing machine (UTM). The compressive strength test was conducted at the Indonesian Institute of Science (LIPI) in Cibinong, Indonesia. Before conducting the test, each of the 120 samples' weights and dimensions were measured to obtain the average compressive strength value. Samples were placed between the steel platen of the UTM with a loading speed of $2 \mathrm{~kg} / \mathrm{cm}^{2} / \mathrm{sec}$ until the samples failed. The compressive strength value obtained was calculated by dividing the maximum force by the loading area.
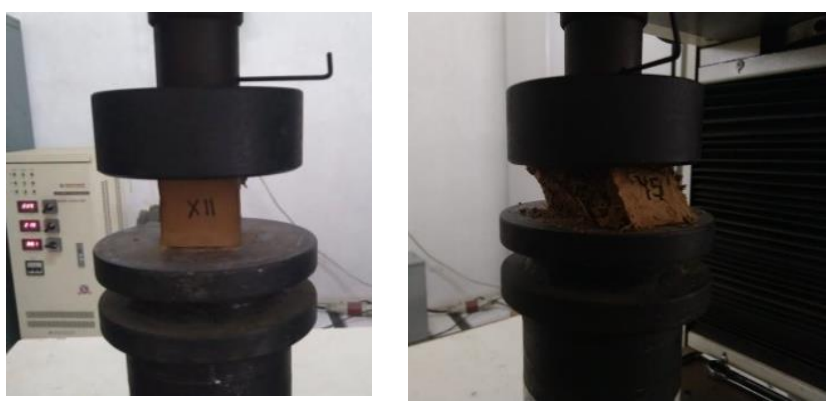

Figure 3 Compressive strength test

\section{Results and Discussion}

The control samples (C1-C30) demonstrated a compressive strength between 1.26 $\mathrm{MPa}-5.88 \mathrm{MPa}$. The average value is $3.92 \mathrm{MPa}$, which indicates that this sample does not meet the Indonesian Standard (SNI) for Class 50 of compressive strength. The compressive strength values of the $\mathrm{X}$ samples (X1-X30) were between 2.84 MPa-5.5 MPa with an average value of $4.26 \mathrm{MPa}$. This average value also does not meet the standard for Class 50 of compressive strength.

Table 2 Compressive strength value

\begin{tabular}{cccc}
\hline Sample & Min. value $(\mathrm{MPa})$ & Max. value $(\mathrm{MPa})$ & Average value $(\mathrm{MPa})$ \\
\hline $\mathrm{C}$ & 1.26 & 5.88 & 3.92 \\
$\mathrm{X}$ & 2.84 & 5.50 & 4.26 \\
$\mathrm{Y}$ & 3.66 & 7.20 & 5.50 \\
$\mathrm{XY}$ & 2.67 & 13.11 & 9.14 \\
\hline
\end{tabular}


The Y samples (Y1-Y30) exhibited a compressive strength value range between 3.66 $\mathrm{MPa}-7.20 \mathrm{MPa}$ with an average value of $5.50 \mathrm{MPa}$. This value meets the Indonesian standard for Class 50 for compressive strength. Finally, the XY samples has a compressive strength value range between 2.67 $\mathrm{MPa}-13.11 \mathrm{MPa}$ with an average value of 9.14 $\mathrm{MPa}$, which also meets the standard for Class 50 for compressive strength.

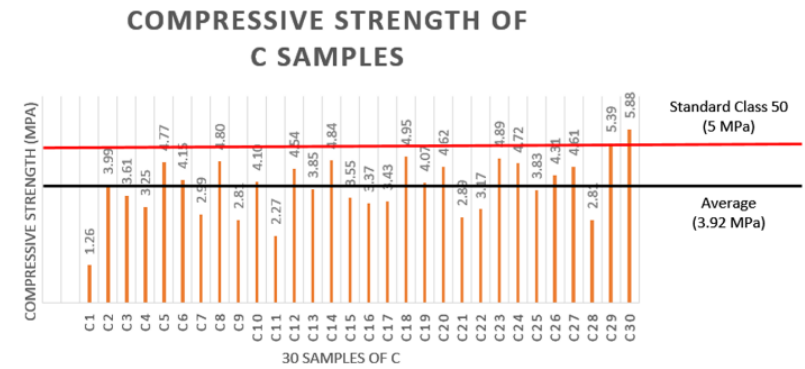

(a)

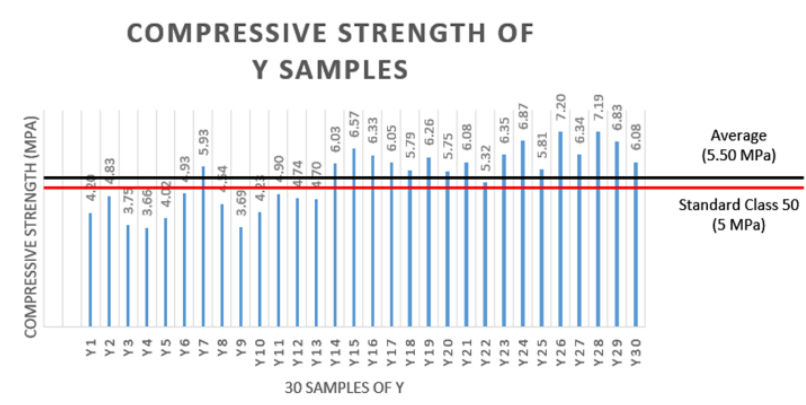

(c)

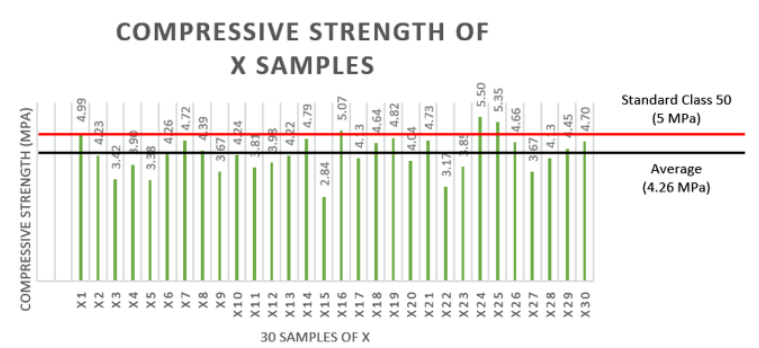

(b)

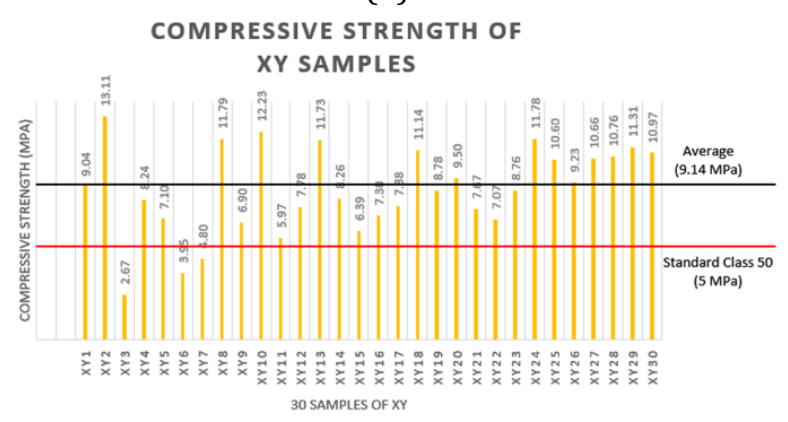

(d)

Figure 4 Graphs of compressive strength: (a) C Samples; (b) X Samples; (c) Y Samples; and (d) XY Samples

Based on the compressive strength test results, the sample order from the lowest to the highest average compressive strength is $\mathrm{C}<\mathrm{X}<\mathrm{Y}<\mathrm{XY}$. The strength of the samples depended on the formation of three bonds: clay-fiber, clay, and fiber. The compressive strength of the $C$ samples were the lowest because no additive materials were present to bond with the clay and increase its strength. The X samples, which contained a bio-enzyme, had slightly higher compressive strength values than the $C$ samples did. This is due to the bio-enzyme acting as a reinforcement in the mixture, which slightly increases compressive strength ratings.

Adding fiber to a clay mixture forms a bond, and this addition is responsible for compressive transmission in soil. This effect is called the fiber bridging mechanism (Salih et al., 2020). This can be seen in the SBF-containing samples, which had higher compressive strength ratings compared to the $C$ and $X$ samples. Compared to the $X$ samples that contained a bio-enzyme only, the $Y$ sample had higher compressive strength value due to the firm binding of clay soil particles resulting from the fiber bridging mechanism.

There are some studies that discuss unfired clay brick using natural fiber reinforcement. In a study conducted by Binici et al. (2005), straw was added to a clay mixture as reinforcement to increase compressive strength with a range between $1.7 \mathrm{MPa}-$ 5.3 MPa. Another study by Njau and Park (2015) demonstrated a compressive strength value range between $1.74 \mathrm{MPa}-6.76 \mathrm{MPa}$ when sisal and coir were added to a brick mixture. In Danso et al. (2015), SBF was added and yielded a product with compressive strength ranging between 1.07 MPa-1.13 MPa. Similarly, Salih et al. (2020) showed that adding SBF increased compressive strength and obtained values between $1.82 \mathrm{MPa}-3.98 \mathrm{MPa}$. 
Compared to previous studies, the results in the above-mentioned research demonstrate higher compressive strength ratings. The Y samples, which contained only SBF, has compressive strength ranges between $3.66 \mathrm{MPa}-7.20 \mathrm{MPa}$ with an average value of 5.50 $\mathrm{MPa}$.
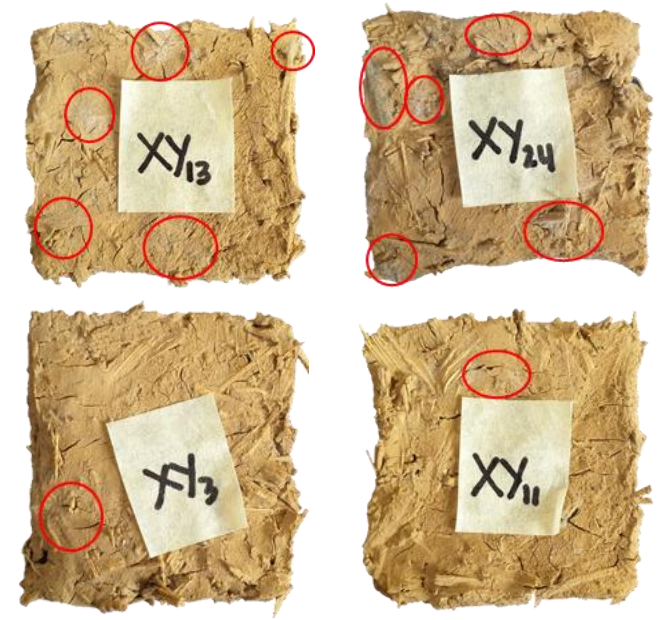

Figure 5 Bio-cementation in XY Samples: Samples with higher compressive strength (top row); Samples with lower compressive strength (bottom row)

The compressive strength of the XY samples with added bio-enzymes and SBF was the highest compared to the other samples. As seen on the surface of the XY samples, the presence of microorganisms led to a bio-cementation process. Like in the research conducted by Dzulkifli et al. (2018), the sample also indicates a bio-cementation process that can be seen directly on the surface of the brick sample, as shown in Figure 5. This occurs because the bio-enzyme stabilizes and increases compressive strength if there is organic matter in the mixture-in this case, SBF. The XY samples had a high rate of deviation, as can be seen in Figure 4d which show that their compressive strength values were substandard. This condition was caused by external factors, such as temperature and humidity, that hindered the bio-cementation process in some samples. Some samples presented fewer white spots; this indicates a slight bio-cementation reaction on the surface, as seen in Figure 5 .

The addition of a bio-enzyme to a brick mixture as liquid content, as well as SBF as reinforcement and organic matter, thus shows promising results in compressive strength compared to the use of natural fibers or bio-enzymes alone.

\section{Conclusions}

The addition of a bio-enzyme and SBF to an unfired clay brick mixture increases the resulting brick's compressive strength. Compressive strength increases by adding a bioenzyme alone, but not significantly so. By adding SBF, the compressive strength of the $Y$ samples increased. However, the samples with both a bio-enzyme and SBF (XY) demonstrated the highest compressive strength out of all other samples. These results highlight how added reinforcements, particularly SBF and bio-enzymes, have the potential to strengthen unfired clay brick. This material is not only lighter compared to fired brick, but it is more environmentally friendly because it requires no kiln-firing.

While improvements in compressive strength have been noted through this study, further research is required to test whether other physical properties of unfired clay brick made with bio-enzymes and SBF, such as water absorption, meets construction standards. 
Additionally, greater variations in the types of soil used, SBF fiber lengths, curing time, raw material ratios, raw material pre-tests, and SEM tests are recommended in further research.

\section{Acknowledgements}

This research was funded by Universitas Indonesia through Publikasi Terindeks Internasional (PUTI) Prosiding 2020 research grant no. NKB1161/UN2.RST/HKP.05.00/2020.

\section{References}

Agunsoye, J.O., Aigbodion, V.S., 2013. Bagasse Filled Recycled Polyethylene Bio-Composite: Morphological and Mechanical Properties Study. Results in Physics, Volume 3(1), pp. 187-194

Binici, H., Aksogan, O., Shah, T., 2005. Investigation of Fibre Reinforced Mud Bricks as a Building Material. Construction and Building Materials, Volume 19(19), pp. 313-318

Chatrada, G., 2009. Bio-Enzyme Stabilized Lateritic and Shedi Soils. Master's Thesis, Graduate Program, National Institute of Technology Karnataka Surathkal, Mangalore, India

Danso, H., Brett Martinson, D., Ali, M., Williams, J., 2015. Effect of Fibre Aspect Ratio on Mechanical Properties of Soil Building Blocks. Construction and Building Materials, Volume 83, pp. 314-319

Deboucha, S., Hashim, R., 2011. A Review on Bricks and Stabilized Compressed Earth Blocks. Scientific Research and Essays, Volume 6(3), pp. 499-506

Dzulkifli, N.A., Omar, R.C., Usman, F., Taha, H., Sanusi, K.A., 2018. Compressive Strength of Vege-Grout Bricks. International Journal of Engineering \& Technology, Volume 7 (4), pp. 516-520

Hall, M., Djerbib, Y., 2004. Rammed Earth Sample Production: Context, Recommendations and Consistency. Construction and Building Materials, Volume 18(4), pp. 281-286

Joglekar, S.N., Kharkar, R.A., Mandavgane, S.A., Kulkarni, B.D., 2018. Sustainability Assessment of Brick Work for Low-cost Housing: A Comparison between Waste Based Bricks and Burnt Clay Bricks. Sustainable Cities and Societies, Volume 37, pp. 396-406

Marcelino-Sadaba, S., Kinuthia, J., Oti, J., Seco Meneses, A., 2017. Challenges in Life Cycle Assessment (LCA) of Stabilised Clay-based Construction Materials. Applied Clay Science, Volume 144, pp. 121-130

Munoz Velasco, P., Morales Ortiz, M.P., Mendivil Giro, M.A., Munoz Velasco, L., 2014. Fired Clay Bricks Manufactured by Adding Waste as Sustainable Construction Material - A Review. Construction and Building Materials, Volume 63, pp. 97-107

National Standardization Agency (BSN), n.d. SNI (Standar Nasional Indonesia)15-20942000: Bata Merah Pejal untuk Pasangan Dinding (Solid Red Brick for Wall Pairs). Office of National Standardization Agency of Indonesia, Jakarta, Indonesia

National Statistics, 2015. Department for Business, Energy \& Industrial Strategy: UK Greenhouse Gas Emissions, Final Figures. Office of National Statistics, UK

Njau, H.G., Park, E., 2015. Compressive Strength of Unfired Composite Bricks Made of Same Clay and Natural Fiber of Tanzania. International Research Journal of Engineering and Technology (IRJET), Volume 2(9), pp. 13-15

Rajoria, V., Kaur, S., 2014. A Review on Stabilization of Soil using Bio-Enzyme. International Journal of Research in Engineering and Technology, Volume 3(1), pp. 75-78

Salih, M.M., Osofero, A.I., Imbabi, M.S., 2020. Constitutive Models for Fibre Reinforced Soil Bricks. Construction and Building Materials, Volume 240, pp. 1-21 
Shubbar, A.A., Jafer, H., Dulaimi, A., Hashim, K., Atherton, W., Sadique., 2018. The Development of a Low Carbon Binder Produced from the Ternary Blending of Cement, Ground Granulated Blast Furnace Slag and High Calcium Fly Ash: An Experimental and Statistical Approach. Construction and Building Materials, Volume 187, pp. 1051-1060

Smith, A.S., Bingel, P., Bown, A., 2016. Sustainability of Masonry in Construction. Sustainability of Construction Materials, Volume 11, pp. 245-282

Vedula, M., Nath, G.P., Chandrasekhar, B.P., 2007. A Critical Review of Innovative Rural Road Construction Techniques and Their Impact. Available Online at https://pdfs.semanticscholar.org/9b75/85edab0bcc70e6eb71b77adae36fb6219a00. pdf, Accessed on July 30, 2020

Yetgin, S., Cavdar, O., Cavdar, A., 2008. The Effects of the Fiber Contents on the Mechanic Properties of the Adobes. Construction and Building Materials, Volume 22(3), pp. 222227

Zhang, L., 2013. Production of Bricks from Waste Materials - A Review. Construction and Building Materials, Volume 47, pp. 643-655 